NBER WORKING PAPER SERIES

\title{
LEVERAGE, INVESTMENT, AND FIRM GROWTH
}

\author{
Larry Lang \\ Eli Ofek \\ René M. Stulz
}

Working Paper No. 5165

\section{NATIONAL BUREAU OF ECONOMIC RESEARCH 1050 Massachusetts Avenue \\ Cambridge, MA 02138 \\ July 1995}

We are grateful for comments from Harry DeAngelo, Tom George, David Mayers, Richard Ruback, Andrei Shleifer, an anonymous referee, and participants at seminars at New York University and Ohio State University. This paper is part of NBER's research programs in Asset Pricing and Corporate Finance. Any opinions expressed are those of the authors and not those of the National Bureau of Economic Research.

() 1995 by Larry Lang, Eli Ofek and Rene M. Stulz. All rights reserved. Short sections of text, not to exceed two paragraphs, may be quoted without explicit permission provided that full credit, including $\odot$ notice, is given to the source. 


\title{
LEVERAGE, INVESTMENT, AND FIRM GROWTH
}

\begin{abstract}
We show that there is a negative relation between leverage and future growth at the firm level and, for diversified firms, at the segment level. Further, this negative relation between leverage and growth holds for firms with low Tobin's $q$, but not for high-q firms or firms in high-q industries. Therefore, leverage does not reduce growth for firms known to have good investment opportunities, but is negatively related to growth for firms whose growth opportunities are either not recognized by the capital markets or are not sufficiently valuable to overcome the effects of their debt overhang.
\end{abstract}

Larry Lang

Department of Finance

Faculty of Business Administration

Chinese University of Hong Kong

Shatin, New Territories

HONG KONG

René M. Stulz

Department of Finance

Fisher College of Business

The Ohio State University

1775 College Road, Room 314

Columbus, $\mathrm{OH} 43210$

and NBER
Eli Ofek

Stern School of Business

Management Education Center

New York University

44 West 4th Street, Suite 9-190

New York, NY 10012-1126 


\section{Introduction}

A central issue in finance is whether leverage affects investment policies. For some, a firm's capital structure is essentially irrelevant. If a firm has good projects, it grows no matter how its balance sheet looks, because it can always find funding. For instance, Miller (1991) argues that we should not "waste our limited worrying capacity on second-order and largely self-correcting problems like financial leveraging." ${ }^{\prime 1}$ For others, high leverage reduces a firm's ability to finance growth through a liquidity effect. ${ }^{2}$ Myers (1977) shows that, in extreme cases, a firm's debt overhang can be large enough to prevent it from raising funds to finance positive net present value (NPV) projects.

This paper examines the relation between leverage and growth over a period of 20 years and finds a strong negative relation. This relation holds irrespective of which variables are used to forecast growth, of how leverage is measured, and of firm size. We show, using regressions of investment on the components of cash flow, that a dollar less of operating cash flow is associated with a smaller decline in investment than a dollar less of cash flow brought about by an increase in debt service.

Management chooses leverage based on its private information about future firm growth. The existing capital structure literature suggests that management of firms with valuable growth opportunities should choose lower leverage because these firms might not be able to take advantage of their investment opportunities if they have to raise outside funds. ${ }^{3}$ Consequently, we could observe a negative relation between future growth and leverage because management of firms with good growth opportunities choose low leverage. Such a result might obtain in regressions that control for growth opportunities because leverage reflects management's information about growth

1 See Miller (1991), p. 481.

${ }^{2}$ See Bernanke, Gertler and Gilchrist (1993) for a review of this literature and Kaplan and Zingales (1995).

${ }^{3}$ See Harris and Raviv (1991) for a review of capital structure theories. 
opportunities. In this case, Miller's dismissal of concerns about leverage would be correct even though there is a negative relation between future growth and leverage.

To address the issue that leverage might proxy for growth opportunities, we use an approach pioneered by Lamont (1993). In a paper on oil companies, he examines whether a contraction in a firm's core segment affects investment in non-core segments. If leverage only proxies for a firm's growth opportunities, we would not expect to observe as strong a relation between growth and leverage for the firm's smaller segments as we do for the firm as a whole and for its main core segment. This is because, in general, the growth opportunities of non-core segments should have less impact on leverage decisions than the growth opportunities of the core segment of a firm. Using the Compustat segment tapes, we show that (1) non-core segment growth is negatively related to leverage, and (2) the extent to which growth is related to leverage is as important for non-core segments as it is for core segments or for the firm as a whole.

Theories of optimal capital structure based on the agency costs of managerial discretion suggest that in some cases, the adverse impact of leverage on growth increases firm value by preventing managers from taking poor projects. ${ }^{4}$ Hence, it could be the case that the negative relation between leverage and growth is due to the fact that leverage restricts managers of firms with poor investment opportunities from investing when they should not. In our sample, the negative relation between leverage and growth holds strongly only for low q firms. These firms do not have valuable investment opportunities known to outside investors. The fact that leverage lowers the growth of such firms is consistent with the agency costs of managerial discretion view of the benefits of debt.

Though several authors have related investment to leverage, they reach conflicting conclusions using approaches that differ substantially from the direct approach used in this paper. First, Whited (1992) shows that investment is more sensitive to cash flow in firms with high leverage

\footnotetext{
${ }^{4}$ See Jensen (1986) and Stulz (1990).
} 
than in firms with low leverage. Cantor (1990) shows that investment is more sensitive to earnings for highly levered firms. Kopcke and Howrey (1994) use balance sheet variables as separate regressors in the investment equation, and argue that these effects are not important. Opler and Titman (1994) show that sales growth is lower for firms in the three highest deciles of leverage, but especially so within distressed industries. When they split their sample by size, they find that leverage has a positive effect on sales growth for large, highly levered firms that are not in distressed industries. Sharpe (1994) shows that the effect of sales growth on employment depends on leverage. In particular, employment for highly levered firms is less sensitive to sales growth during recessions.

The paper proceeds as follows. Section 2 introduces our data. In section 3, we present our results on the correlation between leverage and growth. In section 4, we investigate the relation between leverage and growth for non-core segments of diversified firms. In section 5 , we show that the relation between leverage and growth is driven by the firms in our sample that do not have good investment opportunities. In section 6, we examine the robustness of our results using different samples, measures of growth opportunities, leverage, and growth. Section 7 concludes.

\section{Data}

In this section, we present our main sample. In the following, when we want to distinguish this sample from other samples, we refer to it as the base sample. We have chosen this sample of large industrial firms for several reasons: First, if there is a relation between growth and leverage, we would expect it to be weaker for large firms that are established and have already used public securities markets. Showing the existence of a relation for these firms is more convincing than finding a relation in a sample dominated by small firms. Second, a relation between growth and leverage for small firms has weaker implications for aggregate economic growth than does a relation between growth and leverage for large firms. Third, for these firms, the data we need are generally 
available. Thus, the composition of our sample is not significantly affected by data omissions. This issue is important because, were we to extend our analysis to small firms, a substantial fraction of these firms would not report the complete yearly data we need. The population of firms that report complete data might then be different in subtle ways that might influence our conclusions from the population of firms with incomplete data.

Because of these considerations, we restrict the base sample for each year to firms that have one billion dollars in sales in 1989 dollars. This restriction does not create a sample selection bias, because our analysis focuses on how those firms that meet our size criterion in a given year grow in subsequent years. All our data are obtained from Compustat (including the research tapes). The sample includes the years 1970 to 1989 . We restrict our sample to industrial firms (SIC codes between 2000 and 3999 ) to avoid concems with regulation. Firms included in the base sample must have data on sales, number of employees, and capital expenditures for the base year, year 0 , and year +1 . The base year is the year from which growth is measured. The sample contains 640 different firms; of these 640 firms, 142 firms satisfy our sampling criteria every year.

Throughout the paper, we use three growth measures: The first is net investment in year +1 divided by the book value of fixed assets in year 0 . Net investment is measured as capital expenditures in year +1 minus depreciation. The second measure is the growth rate of real capital expenditures, defined as the ratio of capital expenditures in year +1 adjusted for inflation (using the $\mathrm{CPI}$ ) to the capital expenditures in year 0 , minus one. This measure captures the rate of change of investment. Our final measure is the ratio of the number of employees in year +1 to the number of employees in year 0 , minus one. This measure captures the growth rate of employment. For the growth rate measures, we also use measures computed by taking the ratio of year +3 to year 0 . Table 1 provides summary statistics on our growth measures.

All our main results use the same definition of leverage, namely the ratio of the book value of short-term and long-term debt to the book value of total assets. In comparisons of leverage across 
firms, a market value measure of leverage would give too much importance to recent changes in equity values. If we regress growth measures on a market based leverage measure, we may be regressing growth on the market's expectation of growth as reflected in the firm's stock price. This would imply a negative relation between leverage and growth. In contrast, the book value measure of leverage does not reflect recent changes in the market's valuation of the firm. Table 1 provides statistics for our leverage measure. The spread of leverage is nontrivial for each year in the sample. Typically, the 25 th percentile of leverage is about $40 \%$ lower than the median, and the 75 th percentile is about $20 \%$ higher.

To investigate the relation between growth and leverage, we control for variables that affect the growth measures we use. Therefore, we first control for Tobin's $q$, the ratio of the sum of the book value of debt and market value of equity to the replacement cost of the firm's assets, since firms with higher q's have more valuable growth opportunities. Replacement cost is estimated using the Lindenberg and Ross (1981) algorithm with the modifications described in Lang, Stulz, and Walkling (1989). Table 1 provides summary measures for Tobin's $q$ for the firms in our sample.

We also control for cash flow before interest expense divided by total assets. Recent literature has shown that investment is sensitive to cash flow..$^{5}$ usual cash flow measures are net of interest expense. However, cash flow net of interest expense only partially captures the effect of leverage, because firms with higher interest expense have greater leverage. Consequently, cash flow net of interest expense may proxy for a firm's capital structure rather than for the availability of internal funds for investment. To identify the relation between capital structure and growth, it is therefore better to use a cash flow measure gross of interest, since such a measure is less dependent on a firm's capital structure. ${ }^{\circ}$ Table 1 provides summary statistics for our cash flow

\footnotetext{
${ }^{5}$ See Fazzari, Hubbard, and Petersen (1988) and Hoshi, Kashyap, and Scharfstein (1991) for evidence that investment is related to the availability of internal funds.

${ }^{6}$ This measure is still affected by a firm's capital structure because a firm's tax payments depend on its capital structure.
} 


\section{Table 1}

Growth, leverage, and investment opportunity set measures

The sample period is 1970-1989. Included firms have $\$ 1$ billion of sales in 1989 dollars for each year in which they appear in the sample. All data are obtained from Compustat. Investment is capital expenditures minus depreciation for year +1 divided by the book value of fixed assets at the end of year 0 . Employment growth is the percent change in employment. Capital expenditures growth is the percent change in capital expenditures adjusted for inflation. Book leverage is debt divided by total assets (TA). Market leverage is debt divided by book debt plus market value of equity. All growth measures are obtained by comparing a variable at the end of the year in which the firm enters the sample to its value at the end of the following (three) year for one-year (threeyear) growth measures. Cash flow is gross of interest payments.

\begin{tabular}{|c|c|c|c|c|c|}
\hline & $\begin{array}{l}\text { Mean } \\
\text { (t-statistic) }\end{array}$ & $\begin{array}{l}25 \text { th percen- } \\
\text { tile }\end{array}$ & Median & $\begin{array}{l}\text { 75th percen- } \\
\text { tile }\end{array}$ & $\begin{array}{l}\text { Standard } \\
\text { deviation } \\
\text { (\# of firm- } \\
\text { years) } \\
\end{array}$ \\
\hline $\begin{array}{l}\text { Net invest- } \\
\text { ment/fixed } \\
\text { assets }\end{array}$ & $\begin{array}{c}0.122 \\
(68.04)\end{array}$ & 0.041 & 0.096 & 0.164 & $\begin{array}{l}0.148 \\
(6945)\end{array}$ \\
\hline $\begin{array}{l}\text { 1-year em- } \\
\text { ployment } \\
\text { growth }\end{array}$ & $\begin{array}{l}0.013 \\
(6.84)\end{array}$ & -0.046 & 0.003 & 0.054 & $\begin{array}{l}0.163 \\
(7023)\end{array}$ \\
\hline $\begin{array}{l}\text { 3-year } \\
\text { employment } \\
\text { growth }\end{array}$ & $\begin{array}{l}0.036 \\
(9.12)\end{array}$ & -0.114 & 0.003 & 0.136 & $\begin{array}{c}0.294 \\
(5645)\end{array}$ \\
\hline $\begin{array}{l}\text { 1-year capi- } \\
\text { tal expendi- } \\
\text { tures growth }\end{array}$ & $\begin{array}{c}0.111 \\
(17.48)\end{array}$ & -0.196 & 0.024 & 0.284 & $\begin{array}{l}0.536 \\
(7040)\end{array}$ \\
\hline $\begin{array}{l}\text { 3-year capi- } \\
\text { tal expendi- } \\
\text { tures growth }\end{array}$ & $\begin{array}{r}0.237 \\
(23.59)\end{array}$ & -0.264 & 0.074 & 0.514 & $\begin{array}{l}0.754 \\
(5648)\end{array}$ \\
\hline $\begin{array}{l}\text { Cash flow } \\
\text { TA }\end{array}$ & $\begin{array}{r}0.106 \\
(152.42) \\
\end{array}$ & 0.079 & 0.104 & 0.133 & $\begin{array}{l}0.058 \\
(6915) \\
\end{array}$ \\
\hline Tobin's q & $\begin{array}{r}0.961 \\
(88.04) \\
\end{array}$ & 0.509 & 0.715 & 1.083 & $\begin{array}{c}0.908 \\
(6929) \\
\end{array}$ \\
\hline $\begin{array}{l}\text { Book leve- } \\
\text { rage }\end{array}$ & $\begin{array}{r}0.243 \\
(164.22) \\
\end{array}$ & 0.164 & 0.234 & 0.307 & $\begin{array}{c}0.124 \\
(7049)\end{array}$ \\
\hline $\begin{array}{l}\text { Market } \\
\text { leverage }\end{array}$ & $\begin{array}{r}0.323 \\
(134.28) \\
\end{array}$ & 0.171 & 0.291 & 0.448 & $(7049)^{.203}$ \\
\hline
\end{tabular}


Table 2

Correlations among variables used in this study

The first line gives the correlation between two variables using the raw data; the second line gives the correlation using industry-adjusted variables. Net investment is capital expenditures (CapEX) minus depreciation in year +1 divided by fixed assets $(F A)$ at the end of year 0 . Cash flow is gross of interest expense. * denotes significance at the 0.01 level.

\begin{tabular}{|c|c|c|c|c|c|c|}
\hline & $\begin{array}{l}\text { Net invest- } \\
\text { ment }\end{array}$ & $\begin{array}{c}\text { CapEex } \\
\text { growth, } \\
1 \text { year }\end{array}$ & $\begin{array}{l}\text { CapEx } \\
\text { growth, } \\
3 \text { years }\end{array}$ & $\begin{array}{l}\text { Employ- } \\
\text { ment, } \\
\text { growth } \\
1 \text { year }\end{array}$ & $\begin{array}{l}\quad \text { Em- } \\
\text { ployment, } \\
\text { growth } \\
3 \text { years } \\
\end{array}$ & $\begin{array}{l}\text { Book } \\
\text { leverage }\end{array}$ \\
\hline $\begin{array}{l}\text { Net invest- } \\
\text { ment }\end{array}$ & $\begin{array}{l}1.00 \\
1.00 \\
\end{array}$ & $\begin{array}{l}0.65^{*} \\
0.66^{*}\end{array}$ & $\begin{array}{l}0.08^{*} \\
0.09^{*} \\
\end{array}$ & $\begin{array}{l}0.37^{\star} \\
0.37^{\star}\end{array}$ & $\begin{array}{l}0.23^{*} \\
0.24^{*}\end{array}$ & $\begin{array}{l}-.14^{*} \\
-.10^{*} \\
\end{array}$ \\
\hline $\begin{array}{l}\text { CapEx } \\
\text { growth, } 1 \text { year }\end{array}$ & $\begin{array}{l}0.64^{*} \\
0.66^{*}\end{array}$ & $\begin{array}{l}1.00 \\
1.00 \\
\end{array}$ & $\begin{array}{l}0.40^{*} \\
0.38^{*}\end{array}$ & $\begin{array}{l}0.39^{*} \\
0.37^{*} \\
\end{array}$ & $\begin{array}{l}0.22^{*} \\
0.23^{*}\end{array}$ & $\begin{array}{l}-.11^{*} \\
-.09^{*}\end{array}$ \\
\hline $\begin{array}{l}\text { CapEx } \\
\text { growth, } 3 \\
\text { years }\end{array}$ & $\begin{array}{l}0.08^{*} \\
0.09^{*}\end{array}$ & $\begin{array}{l}0.40^{*} \\
0.38^{*}\end{array}$ & $\begin{array}{l}1.00 \\
1.00\end{array}$ & $\begin{array}{l}0.20^{*} \\
0.16^{*}\end{array}$ & $\begin{array}{l}0.39^{*} \\
0.36^{*}\end{array}$ & $\begin{array}{l}-.09^{*} \\
-.08^{*}\end{array}$ \\
\hline $\begin{array}{l}\text { Employment } \\
\text { growth, } 1 \text { year }\end{array}$ & $\begin{array}{l}0.38^{*} \\
0.37^{*} \\
\end{array}$ & $\begin{array}{l}0.39^{*} \\
0.37^{*}\end{array}$ & $\begin{array}{l}0.20^{*} \\
0.16^{*}\end{array}$ & $\begin{array}{l}1.00 \\
1.00 \\
\end{array}$ & $\begin{array}{l}0.59^{*} \\
0.57^{*} \\
\end{array}$ & $\begin{array}{l}-.08^{*} \\
-.07^{*}\end{array}$ \\
\hline $\begin{array}{l}\text { Employment } \\
\text { growth, } 3 \text { year }\end{array}$ & $\begin{array}{l}0.23^{*} \\
0.24^{*} \\
\end{array}$ & $\begin{array}{l}0.22^{*} \\
0.23^{*}\end{array}$ & $\begin{array}{l}0.39^{*} \\
0.36^{*}\end{array}$ & $\begin{array}{l}0.59^{*} \\
0.57^{*}\end{array}$ & $\begin{array}{l}1.00 \\
1.00 \\
\end{array}$ & $\begin{array}{l}-.11^{*} \\
-.10^{*} \\
\end{array}$ \\
\hline CapEx(0)/FA & $\begin{array}{l}0.26^{*} \\
0.22^{*} \\
\end{array}$ & $\begin{array}{l}-.14^{*} \\
-.13^{*} \\
\end{array}$ & $\begin{array}{l}-.24^{*} \\
-.23^{*}\end{array}$ & $\begin{array}{l}0.07^{*} \\
0.07^{*}\end{array}$ & $\begin{array}{l}0.05^{*} \\
0.04^{*}\end{array}$ & $\begin{array}{l}.01 \\
.035 \\
\end{array}$ \\
\hline Tobin's Q & $\begin{array}{l}0.13^{*} \\
0.15^{*} \\
\end{array}$ & $\begin{array}{l}0.05^{*} \\
0.06^{*} \\
\end{array}$ & $\begin{array}{l}0.07^{*} \\
0.05^{*}\end{array}$ & $\begin{array}{l}0.14^{*} \\
0.11^{*}\end{array}$ & $\begin{array}{l}0.18^{*} \\
0.13^{*}\end{array}$ & $\begin{array}{l}-.19^{*} \\
-.18^{*} \\
\end{array}$ \\
\hline $\begin{array}{l}\text { Cash flow' } \\
\text { TA }\end{array}$ & $\begin{array}{l}0.23^{*} \\
0.18^{*} \\
\end{array}$ & $\begin{array}{l}0.06^{*} \\
0.04 \\
\end{array}$ & $\begin{array}{c}-0.01 * \\
0.00 \\
\end{array}$ & $\begin{array}{l}0.12^{*} \\
0.12^{*}\end{array}$ & $\begin{array}{l}0.14^{*} \\
0.17^{*}\end{array}$ & $\begin{array}{l}-.10^{*} \\
-.02^{*} \\
\end{array}$ \\
\hline $\begin{array}{l}\text { Market } \\
\text { leverage }\end{array}$ & $\begin{array}{l}-.21^{*} \\
-.17^{*}\end{array}$ & $\begin{array}{l}-.13^{*} \\
-.11^{*}\end{array}$ & $\begin{array}{l}-.12^{*} \\
-.09^{*} \\
\end{array}$ & $\begin{array}{l}-.16^{*} \\
-.13^{*} \\
\end{array}$ & $\begin{array}{l}-.21^{*} \\
-.18^{*} \\
\end{array}$ & $\begin{array}{l}0.75^{\star} \\
0.76^{\star}\end{array}$ \\
\hline
\end{tabular}


measure. We also control for sales growth from year -1 to 0 to allow for a multiplier effect.

Table 2 shows the correlations among the variables used in this study. There is a strong negative correlation between book leverage and each growth measure. At the same time, however, leverage is negatively correlated with $q$, and $q$ is positively correlated with all growth measures. In addition, leverage is negatively correlated with cash flow before interest, which itself is positively correlated with all growth measures. Not surprisingly, the correlations of market value leverage (defined as the ratio of book debt to the sum of book debt plus the market value of equity) with the growth measures have the same sign, but are stronger than the correlations of book leverage with the growth measures. Though these correlations lead to the conclusion that there is a negative relation between growth and leverage, this relation could result from the relation between leverage and $q$, cash flow, and accounting eamings. We must therefore consider multivariate regressions which will allow us to estimate the relation between growth and leverage while we control for these other variables. The high correlation between market leverage and book leverage indicates that the choice of a leverage measure may not be very important. In section 6 , we show that our results also hold with the market measure of leverage.

\section{Section 3. Regressions of growth on leverage and other firm characteristics}

In table 3, we present regressions of the growth measures on a constant, leverage, and the control vaniables discussed above, plus indicator variables for each year. Growth can be high for firms in a given year because of the business cycle. If, simultaneously, leverage happens to be low, we might have a negative relation between growth and leverage, because leverage proxies for business cycle effects. To avoid this, we estimate the relation between growth and leverage in regressions with indicator variables for each year. We do not reproduce the coefficients for these indicator variables. In all regressions, we use the White adjustment for heteroskedasticity, since one would expect the error term for individual firms to be correlated within industries. In section 6 , the 


\section{Table 3}

Regressions of growth measures on leverage

The sample period is 1970-1989. Included firms have $\$ 1$ billion of sales in 1989 dollars for each year in which they appear in the sample. All data are obtained from Compustat. CapEx is capital expenditures and de stands for depreciation. $F A(0)$ denotes fixed assets in year 0 . Growth 1 (3) denotes growth measured over one (three) year(s), adjusted for inflation. Book leverage is defined as the ratio of total debt to the book value of total assets. $q$ is defined as the ratio of the market value of equity plus the book value of debt to the replacement cost of the assets. All explanatory variables are computed for the base year; flow variables are normalized using total assets (TA) at the end of the previous year. p-values are in parentheses.

\begin{tabular}{|c|c|c|c|c|c|}
\hline $\begin{array}{c}\text { Dependent } \\
\text { variable } \\
\text { (\# of obs.) }\end{array}$ & $\begin{array}{c}\text { CapEx-de/ } \\
\text { FA(0) } \\
(6791) \\
\end{array}$ & $\begin{array}{c}\text { Employee } \\
\text { growth } 1 \\
(6777) \\
\end{array}$ & $\begin{array}{c}\text { Employee } \\
\text { growth } 3 \\
(5478)\end{array}$ & $\begin{array}{c}\text { CapEx } \\
\text { growth } 1 \\
(6795)\end{array}$ & $\begin{array}{c}\text { CapEx } \\
\text { growth } 3 \\
(5480)\end{array}$ \\
\hline Intercept & $\begin{array}{c}0.002 \\
(0.020)\end{array}$ & $\begin{array}{l}-0.041 \\
(0.001)\end{array}$ & $\begin{array}{c}0.054 \\
(0.019) \\
\end{array}$ & $\begin{array}{c}0.079 \\
(0.055) \\
\end{array}$ & $\begin{array}{r}0.365 \\
(0.001) \\
\end{array}$ \\
\hline $\begin{array}{l}\text { Book lever- } \\
\text { age/TA }\end{array}$ & $\begin{array}{l}-0.105 \\
(0.001) \\
\end{array}$ & $\begin{array}{l}-0.066 \\
(0.001)\end{array}$ & $\begin{array}{l}-0.200 \\
(0.001)\end{array}$ & $\begin{array}{l}-0.480 \\
(0.001)\end{array}$ & $\begin{array}{c}-0.634 \\
(0.001)\end{array}$ \\
\hline $\begin{array}{l}\text { Cash } \\
\text { flow/TA }\end{array}$ & $\begin{array}{c}0.324 \\
(0.001) \\
\end{array}$ & $\begin{array}{c}0.238 \\
(0.001) \\
\end{array}$ & $\begin{array}{c}0.643 \\
(0.001) \\
\end{array}$ & $\begin{array}{c}0.378 \\
(0.039) \\
\end{array}$ & $\begin{array}{c}0.754 \\
(0.011) \\
\end{array}$ \\
\hline $\begin{array}{l}\text { CapEXJ } \\
\text { FA(-1) }\end{array}$ & $\begin{array}{c}0.105 \\
(0.001) \\
\end{array}$ & $\begin{array}{c}0.023 \\
(0.012) \\
\end{array}$ & $\begin{array}{l}-0.015 \\
(0.571) \\
\end{array}$ & $\begin{array}{c}-0.368 \\
(0.012) \\
\end{array}$ & $\begin{array}{l}-1.066 \\
(0.001)\end{array}$ \\
\hline Sales growth & $\begin{array}{c}0.016 \\
(0.068) \\
\end{array}$ & $\begin{array}{c}0.029 \\
(0.007) \\
\end{array}$ & $\begin{array}{c}0.172 \\
(0.001) \\
\end{array}$ & $\begin{array}{c}0.277 \\
(0.001)\end{array}$ & $\begin{array}{c}0.409 \\
(0.001)\end{array}$ \\
\hline Tobin's q & $\begin{array}{c}0.017 \\
(0.001) \\
\end{array}$ & $\begin{array}{c}0.017 \\
(0.001)\end{array}$ & $\begin{array}{c}0.033 \\
(0.001)\end{array}$ & $\begin{array}{c}0.017 \\
(0.014)\end{array}$ & $\begin{array}{c}0.030 \\
(0.016) \\
\end{array}$ \\
\hline R-sq & 0.148 & 0.060 & 0.094 & 0.087 & 0.120 \\
\hline
\end{tabular}


alternative approach of estimating the regressions year by year leads to similar results when we control for variables that might explain growth in the absence of leverage.

Table 3 shows that there is a strong negative relation between book leverage and growth. One way to evaluate this relation is as follows: the average one-year growth in capital expenditures in the sample is $11.1 \%$, and the average book leverage is $24 \%$. Our point estimate for the leverage coefficient implies that a firm that has half the average book leverage would have capital expenditures growth of about $16.9 \%$ instead of $11.1 \%$, a difference of about $50 \%$. Therefore, the relation is economically important. Cash flow has a positive effect on growth for all regressions. The multiplier effect captured by sales growth is significant in all regressions. Capital expenditures are associated with subsequent increases in employment and decreases in capital expenditures growth.

The results in table 3 do not control for industry effects. One approach to controlling for industry effects which is cited in the capital structure literature is that of allowing for industry indicator vaniables. ${ }^{7}$ The problem with this approach is that we are specifically concerned with whether firms that grow more in an industry have higher or lower leverage than other firms in the same industry. Therefore, instead of using industry indicator vanables, it makes more sense to adjust all our variables--except for the year indicator variables-by the industry median. We proceed as follows: For each firm, we compute the number of firms with the same 4-digit SIC code. If there are five or more firms with the same 4-digit code, we subtract from each firm characteristic the median industry value. If there are fewer than five firms with the same 4-digit code, we compute the number of firms with the same 3-digit code. If this does not produce an industry with at least five firms, we then go to the 2-digit code.

Table 4 provides the regression estimates obtained after adjusting all variables for industry effects. Again, we find a strong relation between leverage and growth. The interpretation of the results obtained here is that firms with greater leverage than the industry median grow less than the

\footnotetext{
${ }^{7}$ See, for instance, Bradley, Jarrell and Kim (1984).
} 


\section{Table 4}

Industry-adjusted regressions of growth measures on leverage

The sample period is 1970-1989. Included firms have $\$ 1$ billion of sales in 1989 dollars for each year in which they appear in the sample. All data are obtained from Compustat. Investment is capital expenditures (CapEx) at year 0 minus depreciation (de) divided by fixed assets (FA) at the end of year 0 . Growth 1 (3) denotes growth measured over one (three) year, adjusted for inflation. Book leverage is the ratio of total debt to the book value of total assets. $q$ is the ratio of the market value of equity plus the book value of debt to the replacement cost of the assets. All explanatory variables are computed for the base year; flow variables are normalized using total assets (TA) at the end of the previous year. p-values are in parentheses.

\begin{tabular}{||l|c|c|c|c|c|}
\hline $\begin{array}{c}\text { Dependent } \\
\text { variable } \\
\text { (\# of obs.) }\end{array}$ & $\begin{array}{c}\text { CapEx-de/ } \\
\text { FA(0) } \\
(6791)\end{array}$ & $\begin{array}{c}\text { Employee } \\
\text { growth 1 } \\
(6777)\end{array}$ & $\begin{array}{c}\text { Employee } \\
\text { growth 3 } \\
(5478)\end{array}$ & $\begin{array}{c}\text { CapEx } \\
\text { growth 1 } \\
(6795)\end{array}$ & $\begin{array}{c}\text { CapEx } \\
\text { growth 3 } \\
(5480)\end{array}$ \\
\hline Intercept & $\begin{array}{c}0.002 \\
(0.581)\end{array}$ & $\begin{array}{c}0.003 \\
(0.602)\end{array}$ & $\begin{array}{c}0.033 \\
(0.021)\end{array}$ & $\begin{array}{c}0.081 \\
(0.001)\end{array}$ & $\begin{array}{c}0.158 \\
(0.001)\end{array}$ \\
\hline $\begin{array}{l}\text { Book leve- } \\
\text { rage }\end{array}$ & $\begin{array}{c}-0.089 \\
(0.001)\end{array}$ & $\begin{array}{c}-0.057 \\
(0.008)\end{array}$ & $\begin{array}{c}-0.155 \\
(0.001)\end{array}$ & $\begin{array}{c}-0.428 \\
(0.001)\end{array}$ & $\begin{array}{c}-0.416 \\
(0.001)\end{array}$ \\
\hline Cash & $\begin{array}{c}0.287 \\
\text { flow/TA }\end{array}$ & $\begin{array}{c}0.256 \\
(0.001)\end{array}$ & $\begin{array}{c}0.800 \\
(0.001)\end{array}$ & $\begin{array}{c}0.336 \\
(0.049)\end{array}$ & $\begin{array}{c}0.755 \\
(0.007)\end{array}$ \\
\hline CapEx(0)/FA & $\begin{array}{c}0.088 \\
(0.001)\end{array}$ & $\begin{array}{c}0.014 \\
(0.184)\end{array}$ & $\begin{array}{c}-0.096 \\
(0.001)\end{array}$ & $\begin{array}{c}-0.283 \\
(0.009)\end{array}$ & $\begin{array}{c}-0.813 \\
(0.001)\end{array}$ \\
\hline Sales growth & $\begin{array}{c}0.012 \\
(0.177)\end{array}$ & $\begin{array}{c}0.029 \\
(0.008)\end{array}$ & $\begin{array}{c}0.217 \\
(0.001)\end{array}$ & $\begin{array}{c}0.211 \\
(0.001)\end{array}$ & $\begin{array}{c}0.255 \\
(0.002)\end{array}$ \\
\hline Tobin's q & 0.018 & 0.018 & 0.031 & 0.027 & 0.045 \\
& $(0.001)$ & $(0.001)$ & $(0.001)$ & $(0.002)$ & $(0.004)$ \\
\hline R-sq & 0.079 & 0.026 & 0.049 & 0.036 & 0.055 \\
\hline \hline
\end{tabular}


industry median. This result holds even though we control for cash flow, capital expenditures, sales growth, and q. The control variables have the effect we would expect: Industry-adjusted growth is positively related to industry-adjusted cash flow, sales growth, and q. Typically, q is five times book leverage and ten times cash flow divided by total assets. Therefore, for investment, a firm with twice the median leverage has to have a q equal to twice the median $q$, or a cash flow equal to twice the median cash flow to have investment equal to the median. These results mean that the cash flow, leverage, and q coefficients have almost equal economic significance in the investment equation. For the other growth measures, the economic significance of cash flow is greater than the economic significance of leverage for the employment growth measures, but not for the capital expenditures growth measures. For capital expenditures growth, the economic significance of leverage is greater than the economic significance of $q$; the opposite is the case for the employment growth equations. Another way to look at the economic significance of the coefficient estimates for leverage is this: A firm with leverage equal to twice the industry median will have investment lower than the median by about $17 \%$, one-year employment growth lower by almost $100 \%$, three-year employment growth lower by almost $100 \%$, one-year capital expenditures growth lower by about $80 \%$, and threeyear capital expenditures growth lower by $40 \%$ when the industry medians for these variables are also the sample medians.

One important way to directly assess the economic importance of the relation between leverage and growth is to investigate whether the relation between growth and debt service is stronger than the relation between growth and cash flow. Earlier literature focuses on cash flow net of debt service, thus assuming that the effect on growth of a dollar more of debt service is the same as the effect on growth of a dollar less of cash flow from operations. We have argued here that there should be a multiplier effect of leverage, i.e., that a dollar of debt service reduces liquidity and increases the cost of outside funds. Table 5 provides direct evidence on this issue. For all regressions except the one with three-year capital expenditures growth as the dependent variable, 
the coefficient on debt service is substantially larger in absolute value than the coefficient on cash flow. For the investment equation, the coefficient on debt service is almost twice the coefficient on cash flow in absolute value, suggesting that there is a substantial multiplier effect to leverage compared with cash flow. It follows from this that regressions that consider leverage only through its effect on cash flow net of interest payments seriously underestimate the relation between leverage and firm growth.

One concern about the results in this section is that all our regressions are estimated using ordinary least squares. The use of OLS could bias our coefficients to the extent that leverage is not a predetermined variable, but depends on management's knowledge of the firm's investment opportunities. Although we do not reproduce these results here, we also estimated the relation between growth and leverage in an alternative way. We set up a system of two equations, one for growth and one for leverage, which we estimated simultaneously, allowing leverage to depend on future growth and growth to depend on leverage. Our results for the relation between growth and leverage using this approach are similar to the results reported in this section. Unfortunately, the other regression coefficients seem sensitive to the specification of the two equations, suggesting that the regressions presented in this section are more robust than those estimated in a two-equation system.

\section{Section 4. Leverage and the growth of non-core segments of diversified firms.}

The theoretical capital structure literature implies that firms with valuable growth opportunities should choose low leverage. Smith and Watts (1992) provide supportive evidence in cross-sectional regressions of leverage on growth opportunities and Jung, Kim, and Stulz (1995) show that firms with valuable growth opportunities are more likely to issue equity when they raise external funds. This evidence raises the question of whether we find a relation between growth and leverage because leverage proxies for growth opportunities that are not captured by our other proxies for 
growth opportunities. This problem is of the same nature as a problem found in the literature that relates investment to cash flow. In that literature, a positive relation between investment and cash flow could be accounted for by the role of cash flow as a proxy for investment opportunities. In that literature, it has become common to investigate samples where liquidity differs and growth opportunities are the same. For instance, Hoshi, Kashyap and Scharfstein (1991) compare the relation between cash flow and investment for Japanese firms that belong to a Keiretsu and those that do not. The argument is that, since the Kereitsu provides liquidity, cash flow should not be closely related to growth for Keiretsu firms.

To understand better whether leverage proxies for unobserved growth opportunities, we follow here the strategy employed by Lamont (1993). In this paper, he investigates whether a change in liquidity not associated with a change in growth opportunities affects investment. His insight is to look at non-oil divisions of oil companies when the price of oil falls. These companies suffer a liquidity shock, but this liquidity shock should not correspond to a worsening of the investment opportunities of their non-oil divisions. Hence, evidence that oil companies cut investment in non-oil divisions following a drop in oil prices is evidence supportive of the role of liquidity. Lamont (1993) finds that such cuts take place. Here, we follow the same strategy but with a different motivation and a different sample. When management of a diversified firm chooses its leverage, it does so based on its information about growth opportunities for the firm as a whole. One would not expect, however, the growth opportunities of divisions removed from the core of the firm to have much impact on the firm's capital structure. Consequently, if leverage proxies for growth opportunities, one would expect the relation between leverage and growth to be much stronger for core divisions than for non-core divisions.

To investigate this issue, we use the Compustat segment files from 1986 to 1991. In each firm, we designate a segment as a "core" segment if its 4-digit SIC code is the main SIC code of the firm, and classify other parts as non-core segments. To insure that the firm has segments with 


\section{Table 5}

Industry-adjusted regressions of growth measures on debt service

The sample period is 1970-1989. Included firms have \$1 billion of sales in 1989 dollars for the year in which they appear in the sample. All data are obtained from Compustat. Investment is capital expenditures (CapEx) at year 0 minus depreciation (de) divided by fixed assets (FA) at the end of year 0 . Growth 1 (3) denotes growth measured over one (three) year(s), adjusted for inflation. Debt service is defined as interest paid divided by total assets. $q$ is the ratio of the market value of equity plus the book value of debt to the replacement cost of the assets. All explanatory variables are computed for the base year, flow variables are normalized using total assets (TA) at the end of the previous year. p-values are in parentheses. The last row provides $p$-values for the test that the coefficient on debt service is equal to minus one times the coefficient on cash flow.

\begin{tabular}{|c|c|c|c|c|c|}
\hline $\begin{array}{c}\text { Dependent } \\
\text { variable } \\
\text { (\# of obs.) }\end{array}$ & $\begin{array}{c}\text { CapEx-de/ } \\
\text { FA(0) } \\
(6791) \\
\end{array}$ & $\begin{array}{c}\text { Employee } \\
\text { growth } 1 \\
\text { (6777) }\end{array}$ & $\begin{array}{c}\text { Employee } \\
\text { growth } 3 \\
(5478)\end{array}$ & $\begin{array}{c}\text { CapEx } \\
\text { growth } 1 \\
(6795) \\
\end{array}$ & $\begin{array}{c}\text { CapEx } \\
\text { growth } 3 \\
(5392)\end{array}$ \\
\hline Intercept & $\begin{array}{c}0.003 \\
(0.529) \\
\end{array}$ & $\begin{array}{r}0.003 \\
(0.526) \\
\end{array}$ & $\begin{array}{c}0.034 \\
(0.016)\end{array}$ & $\begin{array}{c}0.082 \\
(0.001)\end{array}$ & $\begin{array}{c}0.159 \\
(0.001) \\
\end{array}$ \\
\hline Debt service & $\begin{array}{c}-0.553 \\
(0.001)\end{array}$ & $\begin{array}{l}-0.740 \\
(0.001) \\
\end{array}$ & $\begin{array}{l}-2.267 \\
(0.001) \\
\end{array}$ & $\begin{array}{l}-2.094 \\
(0.001)\end{array}$ & $\begin{array}{c}-1.852 \\
(0.040) \\
\end{array}$ \\
\hline $\begin{array}{l}\text { Cash } \\
\text { flow/TA }\end{array}$ & $\begin{array}{c}0.292 \\
(0.001)\end{array}$ & $\begin{array}{c}0.251 \\
(0.001)\end{array}$ & $\begin{array}{c}0.777 \\
(0.001)\end{array}$ & $\begin{array}{c}0.368 \\
(0.028)\end{array}$ & $\begin{array}{c}0.784 \\
(0.006) \\
\end{array}$ \\
\hline CapEx(0)/FA & $\begin{array}{c}0.086 \\
(0.001) \\
\end{array}$ & $\begin{array}{c}0.013 \\
(0.250) \\
\end{array}$ & $\begin{array}{l}-0.102 \\
(0.001)\end{array}$ & $\begin{array}{l}-0.291 \\
(0.008)\end{array}$ & $\begin{array}{l}-0.824 \\
(0.001) \\
\end{array}$ \\
\hline Sales growth & $\begin{array}{c}0.011 \\
(0.210)\end{array}$ & $\begin{array}{c}0.030 \\
(0.007) \\
\end{array}$ & $\begin{array}{c}0.220 \\
(0.001)\end{array}$ & $\begin{array}{c}0.202 \\
(0.001) \\
\end{array}$ & $\begin{array}{c}0.246 \\
(0.003)\end{array}$ \\
\hline Tobin's q & $\begin{array}{c}0.019 \\
(0.001) \\
\end{array}$ & $\begin{array}{c}0.018 \\
(0.001)\end{array}$ & $\begin{array}{c}0.029 \\
\langle 0.001)\end{array}$ & $\begin{array}{c}0.033 \\
(0.001)\end{array}$ & $\begin{array}{c}0.051 \\
(0.001)\end{array}$ \\
\hline R-square & 0.077 & 0.027 & 0.055 & 0.030 & 0.052 \\
\hline $\begin{array}{l}\text { p-value for } \\
\text { test of equa- } \\
\text { lity }\end{array}$ & 0.126 & 0.010 & 0.001 & 0.002 & 0.279 \\
\hline
\end{tabular}


sufficiently different growth prospects, we require that the firm has segments in different one-digit SIC codes. We only use segments with $\$ 20$ million of sales or more that are in one-digit SIC codes 2 and 3. With this approach, we obtain 2,566 capital expenditures observations for non-core segments, and 950 capital expenditure observations for core segments. As shown in table 6, the median value of the book value of a firm's core segment to the book value of the firm's total assets (core segment capital expenditures to total capital expenditures) is $0.42(0.47)$, whereas the median value of non-core assets to total assets (non-core segment capital expenditures to total capital expenditures) book value is $0.19(0.20)$.

The Segment Files have limited information about segment investments, assets, and profitability. Consequently, we cannot estimate regressions similar to those estimated in section 3 at the segment level. Further, firms reclassify segments over time so it is difficult to link segment data from year to year. To eliminate this problem, we regress the dependent variable on the segment's ROA for the same period, and on the firm's previous period book leverage. We use two different dependent variables. First, we use a segment's capital expenditures net of depreciation, divided by total assets. This dependent variable is the segment equivalent of the investment measure we used in the previous section. Second, we use a segment's capital expenditures without subtracting depreciation. This measure provides a sense of how financing within the firm is related to leverage. A core division could have net investment related to leverage simply because it has a lot of fixed assets and hence substantial depreciation, even though that division is not growing. Table 6 also provides regression results for industrial firms listed in the Compustat tape with sales of $\$ 20$ million. Thus, the segment level regressions are similar to regressions for firms that satisfy a size cutoff that is similar to the one we use for the segments.

Table 6 provides our regression estimates. We find that the coefficient on leverage is always negative and significant. At the firm level, we find that leverage matters when we estimate similar regressions even when we include firms as small as those with $\$ 20$ million dollars of sales. 
Table 6

Regressions of investment on leverage using segment data

These regressions divide segments of firms in the Compustat Segment Files from 1986 to 1990 between core segments (same 4-digit SIC code as the firm's primary SIC code) and non-core segments. Only segments with $\$ 20$ million in sales of firms that have segments with different one-digit SIC codes are included in a given year. ROA is the return on assets corresponding to the unit of measurement of the dependent variable and is observed in the same year as the dependent variable. Leverage is the firm's book leverage observed the year before. The firm sample includes all industrial firms with sales of $\$ 20$ million in a given year. The sample includes 2,566 non-core segment years, 950 core segment years, and 8,707 firm years.

\begin{tabular}{|c|c|c|c|}
\hline & Non-core segments & Core segments & Firm \\
\hline \multicolumn{4}{|c|}{ Panel A. Medians of selected variables } \\
\hline Segment assets/TA & 0.188 & 0.423 & 1.000 \\
\hline $\begin{array}{l}\text { Segment capital } \\
\text { expenditures/Total } \\
\text { cap. expenditures) }\end{array}$ & 0.198 & 0.472 & 1.000 \\
\hline \multicolumn{4}{|c|}{ Panel B. Capital expenditures minus depreciation to total assets } \\
\hline Constant & $\begin{array}{c}0.025 \\
(0.001)\end{array}$ & $\begin{array}{c}0.031 \\
(0.001)\end{array}$ & $\begin{array}{c}0.017 \\
(0.001) \\
\end{array}$ \\
\hline ROA & $\begin{array}{c}0.027 \\
(0.040)\end{array}$ & $\begin{array}{c}0.042 \\
(0.001) \\
\end{array}$ & $\begin{array}{c}0.151 \\
(0.001) \\
\end{array}$ \\
\hline Leverage & $\begin{array}{c}-0.031 \\
(0.001)\end{array}$ & $\begin{array}{c}-0.047 \\
(0.001)\end{array}$ & $\begin{array}{l}-0.021 \\
(0.001) \\
\end{array}$ \\
\hline R-square & 0.017 & 0.042 & 0.136 \\
\hline \multicolumn{4}{|c|}{ Panel C. Capital expenditures to total assets } \\
\hline Constant & $\begin{array}{c}0.076 \\
(0.001) \\
\end{array}$ & $\begin{array}{c}0.077 \\
(0.001)\end{array}$ & $\begin{array}{c}0.074 \\
(0.001)\end{array}$ \\
\hline ROA & $\begin{array}{c}0.058 \\
(0.001) \\
\end{array}$ & $\begin{array}{c}0.031 \\
(0.001) \\
\end{array}$ & $\begin{array}{c}0.031 \\
(0.001)\end{array}$ \\
\hline Leverage & $\begin{array}{c}-0.039 \\
(0.001)\end{array}$ & $\begin{array}{c}-0.030 \\
(0.001) \\
\end{array}$ & $\begin{array}{l}-0.027 \\
(0.001) \\
\end{array}$ \\
\hline R-square & 0.035 & 0.018 & 0.017 \\
\hline
\end{tabular}


Comparing the coefficients on leverage between the firm regressions and the non-core segment regressions, there is little difference. Throughout the table, there is no evidence to support the view that the capital expenditures of non-core segments are less sensitive to leverage than the capital expenditures of firms. Compared to core segments, we find that for capital expenditures minus depreciation divided by total assets, the coefficient on leverage is larger in absolute value for core segments than for non-core segments; the opposite holds for capital expenditures divided by total assets. The evidence in table 6 does not seem consistent with the argument that the negative relation between leverage and growth obtains because the endogeneity of leverage makes it a good proxy for growth.

The extent to which our evidence in this section attenuates concerns about the proxy issue depends on whether our definition of core segments is appropriate. In table 7, we use two different definitions of core segments. First, we identify as a core segment any segment that has the same two-digit SIC code as the firm's primary two-digit SIC code. Second, we avoid using SIC codes altogether and identify as the core segment the segment that has the largest sales. It is interesting that in this case the median ratio of core segment assets to firm assets is the highest, 0.460 , and that the core segment defined this way receives more than half the firm's total capital expenditures. Nevertheless, the results of table 6 still hold irrespective of the definition of the core segment. In fact, when the core segment is defined as the segment with the largest sales, the leverage coefficient is just about the same for core and non-core segments $(-0.036$ versus -0.037$)$. As in table 6 , the leverage coefficient is higher for non-core segments when the measure of growth is capital expenditures gross of depreciation. In table 8, we investigate whether our results are sensitive to the measure of leverage used. We estimate our regressions using three different measures of leverage: interest payments relative to total assets, market leverage, and the ratio of long-term debt to total assets. Again, we find that non-core investment is negatively related to leverage. The coefficient on leverage is greater in absolute value for core investment when the dependent variable is 


\section{Table 7}

Regressions of investment on leverage using segment data and different definitions of core segments

These regressions divide segments of firms in the Compustat Segment Files from 1986 to 1990 between core segments and non-core segments. Only segments with $\$ 20$ million in sales of firms that have segments with different one-digit SIC codes are included in a given year. ROA is the return on assets corresponding to the unit of measurement of the dependent variable and is observed in the same year as the dependent variable. CapEx denotes capital expenditures. Leverage is the firm's book leverage observed the year before. TA denotes total assets.

Panel A: Medians of selected variables.

\begin{tabular}{||c|c|c|c|c|}
\hline & \multicolumn{2}{|c|}{ Segment assets/Firm assets } & \multicolumn{2}{c|}{ Segment CapEx/Firm CapEx } \\
\hline & Core & Non-core & Core & Non-core \\
\hline $\begin{array}{l}\text { Panel B defi- } \\
\text { nition }\end{array}$ & 0.335 & 0.165 & 0.380 & 0.174 \\
\hline $\begin{array}{l}\text { Panel A defi- } \\
\text { nition }\end{array}$ & 0.460 & 0.154 & 0.528 & 0.162 \\
\hline
\end{tabular}

Panel B: Core segment defined as any segment that has the same 2 digit SIC code as the firm.

\begin{tabular}{||l|r|r|r|r||}
\hline & \multicolumn{2}{|c|}{ CapEx-depreciation/TA } & \multicolumn{2}{|c|}{ CapEx/TA } \\
\hline & Non-Core & Core & Non-Core & Core \\
\hline Intercept & $\begin{array}{c}0.021 \\
(0.001)\end{array}$ & $\begin{array}{c}0.034 \\
(0.001)\end{array}$ & $\begin{array}{c}0.078 \\
(0.001)\end{array}$ & $\begin{array}{c}0.075 \\
(0.001)\end{array}$ \\
\hline Leverage & $\begin{array}{c}-0.026 \\
(0.001)\end{array}$ & $\begin{array}{c}-0.046 \\
(0.001)\end{array}$ & $\begin{array}{c}-0.041 \\
(0.001)\end{array}$ & $\begin{array}{c}0.032 \\
(0.001)\end{array}$ \\
\hline ROA & $\begin{array}{c}0.051 \\
(0.001)\end{array}$ & $\begin{array}{c}0.010 \\
(0.539)\end{array}$ & $\begin{array}{c}0.046 \\
(0.001)\end{array}$ & $\begin{array}{c}0.056 \\
(0.014)\end{array}$ \\
\hline R-square & 0.025 & 0.028 & 0.024 & 0.033 \\
\hline
\end{tabular}




\begin{tabular}{||l|r|r|r|r||}
\hline \multirow{2}{*}{ Panel C: Core segment defined as segment with largest sales. } \\
\hline & Non-Core & Core & Non-Core & Core \\
\hline \multirow{2}{*}{ Intercept } & $\begin{array}{r}0.024 \\
(0.001)\end{array}$ & $\begin{array}{c}0.034 \\
(0.001)\end{array}$ & $\begin{array}{c}0.078 \\
(0.001)\end{array}$ & $\begin{array}{c}0.072 \\
(0.001)\end{array}$ \\
\hline Leverage & $\begin{array}{c}-0.036 \\
(0.001)\end{array}$ & $\begin{array}{c}-0.037 \\
(0.001)\end{array}$ & $\begin{array}{c}-0.043 \\
(0.001)\end{array}$ & $\begin{array}{c}-0.027 \\
(0.001)\end{array}$ \\
\hline ROA & $\begin{array}{c}0.039 \\
(0.001)\end{array}$ & $\begin{array}{c}0.010 \\
(0.628)\end{array}$ & $\begin{array}{c}0.039 \\
(0.001)\end{array}$ & $\begin{array}{c}0.077 \\
0.021)\end{array}$ \\
\hline R-square & 0.026 & 0.018 & 0.029 & 0.036 \\
\hline
\end{tabular}




\begin{tabular}{|c|c|c|c|c|c|c|}
\hline \multicolumn{7}{|c|}{$\begin{array}{l}\text { Table } 8 \\
\text { Regressions of investment on leverage using segment data and different definitions } \\
\text { of core segments }\end{array}$} \\
\hline \multicolumn{7}{|c|}{ Panel A: (Capital expenditures-Depreciation)/Segment's assets } \\
\hline & Non Core & Core & Non Core & Core & Non Core & Core \\
\hline Intercept & $\begin{array}{c}0.025 \\
(0.001) \\
\end{array}$ & $\begin{array}{r}0.030 \\
(0.001) \\
\end{array}$ & $\begin{array}{c}0.029 \\
(0.001) \\
\end{array}$ & $\begin{array}{c}0.031 \\
(0.001) \\
\end{array}$ & $\begin{array}{c}0.023 \\
(0.001) \\
\end{array}$ & $\begin{array}{r}0.029 \\
(0.001) \\
\end{array}$ \\
\hline Interest/Assets & $\begin{array}{c}-0.292 \\
(0.001) \\
\end{array}$ & $\begin{array}{l}-0.379 \\
(0.001) \\
\end{array}$ & & & & \\
\hline Market leverage & & & $\begin{array}{c}-0.033 \\
(0.001) \\
\end{array}$ & $\begin{array}{c}-0.035 \\
(0.001) \\
\end{array}$ & & \\
\hline $\begin{array}{l}\text { Long term } \\
\text { leverage }\end{array}$ & & & & & $\begin{array}{l}-0.030 \\
(0.001) \\
\end{array}$ & $\begin{array}{c}-0.049 \\
(0.006) \\
\end{array}$ \\
\hline ROA & $\begin{array}{c}0.026 \\
(0.044)\end{array}$ & $\begin{array}{c}0.044 \\
(0.001)\end{array}$ & $\begin{array}{c}0.018 \\
(0.159)\end{array}$ & $\begin{array}{c}0.035 \\
(0.011)\end{array}$ & $\begin{array}{c}0.029 \\
(0.023) \\
\end{array}$ & $\begin{array}{c}0.041 \\
(0.002) \\
\end{array}$ \\
\hline R-square & 0.020 & 0.046 & 0.038 & 0.023 & 0.022 & 0.034 \\
\hline \multicolumn{7}{|c|}{ Panel B: Capital expenditures/Segment's assets } \\
\hline & Non Core & Core & Non Core & Core & Non Core & Core \\
\hline Intercept & $\begin{array}{c}0.076 \\
(0.001) \\
\end{array}$ & $\begin{array}{c}0.077 \\
(0.001) \\
\end{array}$ & $\begin{array}{c}0.080 \\
(0.001) \\
\end{array}$ & $\begin{array}{c}0.081 \\
(0.001) \\
\end{array}$ & $\begin{array}{c}0.072 \\
(0.001) \\
\end{array}$ & $\begin{array}{c}0.074 \\
(0.001) \\
\end{array}$ \\
\hline Interest/Assets & $\begin{array}{l}-0.354 \\
(0.001) \\
\end{array}$ & $\begin{array}{l}-0.283 \\
(0.001) \\
\end{array}$ & & & & \\
\hline Market leverage & & & $\begin{array}{l}-0.040 \\
(0.001) \\
\end{array}$ & $\begin{array}{l}-0.034 \\
(0.001) \\
\end{array}$ & & \\
\hline $\begin{array}{l}\text { Long term } \\
\text { leverage }\end{array}$ & & & & & $\begin{array}{l}-0.035 \\
(0.001) \\
\end{array}$ & $\begin{array}{l}-0.025 \\
(0.012) \\
\end{array}$ \\
\hline ROA & $\begin{array}{c}0.056 \\
(0.001)\end{array}$ & $\begin{array}{c}0.032 \\
(0.046)\end{array}$ & $\begin{array}{c}0.045 \\
(0.006)\end{array}$ & $\begin{array}{c}0.022 \\
(0.181)\end{array}$ & $\begin{array}{c}0.060 \\
(0.001)\end{array}$ & $\begin{array}{c}0.031 \\
(0.053)\end{array}$ \\
\hline R-square & 0.039 & 0.025 & 0.014 & 0.035 & 0.030 & 0.012 \\
\hline
\end{tabular}


investment net of depreciation and is smaller for core investment when the dependent variable is investment gross of depreciation. Finally, we investigated whether the results reported here hold year by year as well. In regressions not reported here, we found that the relation documented in table 6 holds for every year in our sample.

\section{Section 5. Growth opportunities and leverage}

We have documented a strong negative relation between leverage and growth at the firm and segment levels. This raises the question of whether leverage uniformly lowers growth regardless of whether a firm has good investment opportunities. Much of finance theory implies that leverage should have less of an effect for firms whose valuable investment opportunities are recognized by the capital markets, i.e., high-q firms. In contrast, for firms doing poorly because of a lack of recognized investment opportunities, poor managerial performance, or other reasons, leverage should have a negative effect on growth. The cost of capital of these firms increases with their leverage because, in contrast to firms with valuable investment opportunities, it is not clear that funds raised extemally will be used profitably. In this section, we investigate this hypothesis.

The alternative hypothesis is what we call the "naive liquidity effect," namely that leverage reduces investment and growth irrespective of investment opportunities. An alternative liquidity argument is that leverage should reduce growth more for firms with valuable growth opportunities, because such firms have greater informational asymmetries, thus outside funds are more expensive for them.

Table 9 provides evidence on what happens to the relation between growth and leverage when growth opportunities are allowed to affect the impact of leverage on growth. In the regressions shown in table 9, we allow the relation between leverage and $q$ to differ between high- and low-q firms, where high-q firms are firms with $q>1$. The $p$-values for the difference in the leverage coefficients for high and low $q$ firms are not reported, since in all cases the coefficients are different 
Table 9

Investment opportunities and the relation between growth and leverage

The sample period is 1970-1989. Included firms have \$1 billion of sales in 1989 dollars for each year in which they appear in the sample. All data are obtained from Compustat. CapEx is capital expenditures. De stands for depreciation. $F A(0)$ is the book value of fixed assets at the end of the base year. Growth 1 (3) denotes growth measured over one (three) year(s), adjusted for inflation. Book leverage is defined as the ratio of total debt to the book value of total assets. $q$ is the ratio of the market value of equity plus the book value of debt to the replacement cost of the assets. All explanatory variables are computed for the base year; flow variables are normalized using total assets (TA) at the end of the previous year. p-values are in parentheses.

\begin{tabular}{||l|l|l|l|l|c||}
\hline Dependent variable & $\begin{array}{l}\text { CapEx-de } \\
\text { \#fA(0) } \\
6791\end{array}$ & $\begin{array}{l}\text { Employee } \\
\text { growth 1 } \\
6777\end{array}$ & $\begin{array}{l}\text { Employee } \\
\text { growth 3 } \\
5478\end{array}$ & $\begin{array}{l}\text { CapEx } \\
\text { growth 1 } \\
6795\end{array}$ & $\begin{array}{l}\text { CapEx } \\
\text { growth 3 } \\
5480\end{array}$ \\
\hline Intercept & $\begin{array}{c}0.025 \\
(0.012)\end{array}$ & $\begin{array}{c}-0.039 \\
(0.001)\end{array}$ & $\begin{array}{c}0.055 \\
(0.014)\end{array}$ & $\begin{array}{c}0.083 \\
(0.048)\end{array}$ & $\begin{array}{c}0.368 \\
(0.001)\end{array}$ \\
\hline Book leverage, q<1 & $\begin{array}{c}-0.125 \\
(0.001)\end{array}$ & $\begin{array}{c}-0.091 \\
(0.001)\end{array}$ & $\begin{array}{c}-0.249 \\
(0.001)\end{array}$ & $\begin{array}{c}-0.531 \\
(0.001)\end{array}$ & $\begin{array}{c}-0.747 \\
(0.001)\end{array}$ \\
\hline Book leverage, q>1 & $\begin{array}{c}-0.035 \\
(0.175)\end{array}$ & $\begin{array}{c}0.025 \\
(0.377)\end{array}$ & $\begin{array}{c}0.011 \\
(0.851)\end{array}$ & $\begin{array}{c}-0.305 \\
(0.001)\end{array}$ & $\begin{array}{c}-0.140 \\
(0.282)\end{array}$ \\
\hline Cash flow/TA & $\begin{array}{c}0.311 \\
(0.001)\end{array}$ & $\begin{array}{c}0.222 \\
(0.001)\end{array}$ & $\begin{array}{c}0.590 \\
(0.001)\end{array}$ & $\begin{array}{c}0.349 \\
(0.054)\end{array}$ & $\begin{array}{c}0.632 \\
(0.036)\end{array}$ \\
\hline CapEx(0)/FA & $\begin{array}{c}0.105 \\
(0.001)\end{array}$ & $\begin{array}{c}0.022 \\
(0.028)\end{array}$ & $\begin{array}{c}-0.023 \\
(0.407)\end{array}$ & $\begin{array}{c}-0.370 \\
(0.013)\end{array}$ & $\begin{array}{c}-1.084 \\
0.001)\end{array}$ \\
\hline Sales growth & $\begin{array}{c}0.013 \\
(0.144)\end{array}$ & $\begin{array}{c}0.026 \\
(0.011)\end{array}$ & $\begin{array}{c}0.161 \\
(0.001)\end{array}$ & $\begin{array}{c}0.271 \\
(0.001)\end{array}$ & $\begin{array}{c}0.384 \\
(0.001)\end{array}$ \\
\hline Tobin's q & $\begin{array}{c}0.012 \\
(0.001)\end{array}$ & $\begin{array}{c}0.011 \\
(0.001)\end{array}$ & $\begin{array}{c}0.022 \\
(0.001)\end{array}$ & $\begin{array}{c}0.007 \\
(0.311)\end{array}$ & $\begin{array}{c}0.006 \\
(0.634)\end{array}$ \\
\hline R-sq & 0.151 & 0.064 & 0.101 & 0.088 & 0.126 \\
\hline \hline
\end{tabular}


at the 0.01 level. These regressions indicate that investment, employment, and investment growth for low-q firms is significantly negatively related to leverage. In contrast, for four out of five regressions, there is no significant relation between growth and leverage for high-q firms. In half these cases, the estimated coefficient is positive. For investment growth, leverage has a significant negative coefficient for high-q firms, but the coefficient is three-fifths what it is for the low-q firms. The strong negative relation between growth and leverage for the whole sample therefore becomes largely insignificant when we focus on high-q firms. This implies that the difficulties of borrowing against growth opportunities are not a serious impediment when these opportunities are recognized by outside investors. Therefore, if leverage reduces growth, it is through the inability of highly levered firms with poor or unrecognized investment opportunities to obtain external funding for growth.

Capital structure theories suggest that firms with good investment opportunities should have low leverage. This means that if the causal relation runs only from growth to leverage, we would expect a negative relation between leverage and growth for high-q firms. Since we find no such relation, it is important to investigate if the reason is that firms take capital structure theories so seriously that there is no variation in capital structure for those with good investment opportunities. Our results are not explained by a lack of variation in leverage for high-q firms, however. Not surprisingly, both the mean and median of leverage are lower for high-q firms. The interquartile range for high-q firms is 0.157 around a median of 0.199 whereas the interquartile range for low-q firms is 0.132 around a median of 0.244 . However, the ranges for high- and low-q firms are similar. More than $25 \%$ the high-q firms have leverage in excess of the median leverage of low $q$ firms. Consequently, variation in leverage is substantial for both high-q and low-q firms. Our results show that this variation does not explain cross-sectional variation in growth for high-q firms, but does explain this cross-sectional variation for low-q firms.

Because of the existence of industry effects for leverage emphasized by Bradley, Jarrell, and Kim (1984), it is important to investigate whether our results reflect the fact that, even though we 
Table 10

Industry investment opportunities and the relation between growth and leverage: Industry-adjusted results

The sample period is 1970-1989. Included firms have $\$ 1$ billion of sales in 1989 dollars for each year in which they appear in the sample. All data are obtained from Compustat. CapEx is capital expenditures. De stands for depreciation. $F A(0)$ is the book value of fixed assets at the end of the base year. Growth 1 (3) denotes growth measured over one (three) year(s), adjusting for inflation. Book leverage is the ratio of total debt to the book value of total assets. $q$ is the ratio of the market value of equity plus the book value of debt to the replacement cost of the assets. All explanatory variables are computed for the base year; flow variables are normalized using total assets (TA) at the end of the previous year. $p$ values are in parentheses.

\begin{tabular}{||l|c|c|c|c|c||}
\hline $\begin{array}{l}\text { Dependent } \\
\text { variable } \\
\text { \# of obs }\end{array}$ & $\begin{array}{l}\text { CapEx-de } \\
\text { IFA(0) } \\
6791\end{array}$ & $\begin{array}{l}\text { Employee } \\
\text { growth 1 } \\
6777\end{array}$ & $\begin{array}{l}\text { Employee } \\
\text { growth 3 } \\
5478\end{array}$ & $\begin{array}{l}\text { CapEx } \\
\text { growth 1 } \\
6795\end{array}$ & $\begin{array}{l}\text { CapEx } \\
\text { growth 3 } \\
5480\end{array}$ \\
\hline Intercept & $\begin{array}{c}0.003 \\
(0.477)\end{array}$ & $\begin{array}{c}0.004 \\
(0.493)\end{array}$ & $\begin{array}{c}0.035 \\
(0.015)\end{array}$ & $\begin{array}{c}0.083 \\
(0.001)\end{array}$ & $\begin{array}{c}0.162 \\
(0.001)\end{array}$ \\
\hline Book leverage, q<1 & $\begin{array}{c}-0.118 \\
(0.001)\end{array}$ & $\begin{array}{c}-0.098 \\
(0.001)\end{array}$ & $\begin{array}{c}-0.238 \\
(0.001)\end{array}$ & $\begin{array}{c}-0.516 \\
(0.001)\end{array}$ & $\begin{array}{c}-0.585 \\
(0.001)\end{array}$ \\
\hline Book leverage, q>1 & $\begin{array}{c}-0.016 \\
(0.660)\end{array}$ & $\begin{array}{c}0.047 \\
(0.292)\end{array}$ & $\begin{array}{c}0.064 \\
(0.412)\end{array}$ & $\begin{array}{c}-0.205 \\
(0.056)\end{array}$ & $\begin{array}{c}0.035 \\
(0.846)\end{array}$ \\
\hline Cash flow/TA & $\begin{array}{c}0.284 \\
(0.001)\end{array}$ & $\begin{array}{c}0.252 \\
(0.001)\end{array}$ & $\begin{array}{c}0.774 \\
(0.001)\end{array}$ & $\begin{array}{c}0.327 \\
(0.052)\end{array}$ & $\begin{array}{c}0.700 \\
(0.014)\end{array}$ \\
\hline CapEx(0)/FA & $\begin{array}{c}0.088 \\
(0.001)\end{array}$ & $\begin{array}{c}0.015 \\
(0.182)\end{array}$ & $\begin{array}{c}-0.095 \\
(0.001)\end{array}$ & $\begin{array}{c}-0.282 \\
(0.010)\end{array}$ & $\begin{array}{c}-0.812 \\
(0.001)\end{array}$ \\
\hline Sales growth & $\begin{array}{c}0.011 \\
(0.259)\end{array}$ & $\begin{array}{c}0.027 \\
(0.011)\end{array}$ & $\begin{array}{c}0.213 \\
(0.001)\end{array}$ & $\begin{array}{c}0.206 \\
(0.001)\end{array}$ & $\begin{array}{c}0.247 \\
(0.003)\end{array}$ \\
\hline Tobin's q & $\begin{array}{c}0.020 \\
(0.001)\end{array}$ & $\begin{array}{c}0.020 \\
(0.001)\end{array}$ & $\begin{array}{c}0.036 \\
(0.001)\end{array}$ & $\begin{array}{c}0.032 \\
(0.001)\end{array}$ & $\begin{array}{c}0.055 \\
(0.002)\end{array}$ \\
\hline R-sq & 0.086 & 0.027 & 0.052 & 0.037 & 0.056 \\
\hline $\begin{array}{l}\text { p-value for dif- } \\
\text { ference in leverage } \\
\text { coefficients }\end{array}$ & \begin{tabular}{c}
0.011 \\
\hline
\end{tabular} & 0.004 & 0.001 & 0.016 & 0.004 \\
\hline
\end{tabular}


have variation in leverage, this variation is only across industries, so that leverage is a proxy for industry effects. Table 10 shows that, when we use industry-adjusted data, there is no relation between leverage and growth for high-q industries.

\section{Section 6. Alternative specifications and samples}

In this section, we investigate the robustness of the result that there is a strong negative relation between leverage and growth for low-q firms but not for high-q firms. To do so, we change the sample and the measures of leverage and growth opportunities.

In the regressions presented so far, we used book leverage as our measure of leverage. In table 11, we present results using alternative measures of leverage. We only show results for the investment and employee growth regressions, since the other regressions lead to similar inferences. For all measures except market leverage, there is a significant negative relation between growth and leverage for low-q firms, and no significant relation for high-q firms. Note, however, that one of our measures is book equity divided by total assets; for this measure, leverage falls as the variable increases. The coefficient on this variable is therefore positive and significant for low-q firms. For market leverage, there is a significant negative relation between growth and leverage for both highand low-q firms. Further, the difference between the coefficients on leverage for high and low $q$ firms is small and insignificant. These regressions show that using market leverage can lead to different results. This is not too surprising, since the firms with the highest market leverage tend to be the firms with the worst growth opportunities for given book leverage.

In our previous analysis, we only considered $q$ as a measure of investment opportunities. In table 12, we use alternative measures of investment opportunities. Two of these measures are forward-looking; one is not. One concern is that we might have a situation where leverage kills off growth opportunities altogether, so that whenever leverage matters, firms have q's less than one. A test that investigates whether this concern is legitimate uses the industry $q$ as a measure of 
Table 11

Alternative leverage measures

The sample period is 1970-1989. Included firms have \$1 billion of sales in 1989 dollars for each year in which they appear in the sample. All data are obtained from Compustat. CapEx is capital expenditures. De stands for depreciation. $F A(0)$ is the book value of fixed assets at the end of the base year. Emp. growth is the percentage increase in employees from the base year to year +1 . Book leverage is the ratio of total debt to the book value of total assets at the end of the based year (TA). Market leverage is debt divided by the sum of debt plus the market value of equity. Interest denotes interest expense. Equity is the book value of equity. p-values are in parentheses.

\begin{tabular}{|c|c|c|c|c|c|c|c|c|}
\hline $\begin{array}{l}\text { Dependent } \\
\text { variable } \\
\text { \# of obs }\end{array}$ & $\begin{array}{l}\text { CapEx- } \\
\text { de } \\
\text { /FA(0) } \\
6791\end{array}$ & $\begin{array}{l}\text { Emp. } \\
\text { growth } \\
6777\end{array}$ & $\begin{array}{l}\text { CapEx- } \\
\text {-de } \\
\text { /FA(0) } \\
6791\end{array}$ & $\begin{array}{l}\text { Emp. } \\
\text { growth } \\
6777\end{array}$ & $\begin{array}{l}\text { CapEx } \\
\text {-de } \\
\text { IFA(0) } \\
6780 \\
\end{array}$ & $\begin{array}{l}\text { Emp. } \\
\text { growth } \\
6766\end{array}$ & $\begin{array}{l}\text { CapEx- } \\
\text { de } \\
\text { /FA(0) } \\
6791\end{array}$ & $\begin{array}{l}\text { Emp. } \\
\text { growth } \\
6777\end{array}$ \\
\hline Intercept & $\begin{array}{c}0.005 \\
(0.244)\end{array}$ & $\begin{array}{r}0.006 \\
(0.255) \\
\end{array}$ & $\begin{array}{c}0.003 \\
(0.491) \\
\end{array}$ & $\begin{array}{c}0.004 \\
(0.485) \\
\end{array}$ & $\begin{array}{r}0.003 \\
(0.495) \\
\end{array}$ & $\begin{array}{r}0.003 \\
(0.508) \\
\end{array}$ & $\begin{array}{r}0.003 \\
(0.464) \\
\end{array}$ & $\begin{array}{r}0.003 \\
(0.575) \\
\end{array}$ \\
\hline $\begin{array}{l}\text { Market lever- } \\
\text { age, } q<1\end{array}$ & $\begin{array}{l}-0.097 \\
(0.001)\end{array}$ & $\begin{array}{l}-0.085 \\
(0.001)\end{array}$ & & & & & & \\
\hline $\begin{array}{l}\text { Market lever- } \\
\text { age, } q>1\end{array}$ & $\begin{array}{l}-0.089 \\
(0.001)\end{array}$ & $\begin{array}{l}-0.033 \\
(0.294) \\
\end{array}$ & & & & & & \\
\hline Interest $/ T A, q<1$ & & & $\begin{array}{l}-0.683 \\
(0.001)\end{array}$ & $\begin{array}{l}-0.953 \\
(0.001) \\
\end{array}$ & & & & \\
\hline Interest $/ T A, q>1$ & & & $\begin{array}{l}-0.015 \\
(0.969) \\
\end{array}$ & $\begin{array}{r}0.149 \\
(0.682) \\
\end{array}$ & & & & \\
\hline $\begin{array}{l}\text { Book equity/TA } \\
q<1\end{array}$ & & & & & $\begin{array}{c}0.052 \\
(0.001) \\
\end{array}$ & $\begin{array}{c}0.054 \\
(0.001) \\
\end{array}$ & & \\
\hline $\begin{array}{l}\text { Book equity/TA } \\
q>1\end{array}$ & & & & & $\begin{array}{l}-0.008 \\
(0.749)\end{array}$ & $\begin{array}{l}-0.037 \\
(0.253) \\
\end{array}$ & & \\
\hline $\begin{array}{l}\text { Long-term } \\
\text { debt/TA } q<1\end{array}$ & & & & & & & $\begin{array}{l}-0.125 \\
(0.001) \\
\end{array}$ & $\begin{array}{l}-0.086 \\
(0.001) \\
\end{array}$ \\
\hline $\begin{array}{l}\text { Long-term } \\
\text { debt/TA } g>1\end{array}$ & & & & & & & $\begin{array}{l}-0.031 \\
(0.396) \\
\end{array}$ & $\begin{array}{c}0.064 \\
(0.234) \\
\end{array}$ \\
\hline Cash flow/TA & $\begin{array}{r}0.239 \\
(0.001) \\
\end{array}$ & $\begin{array}{c}0.220 \\
(0.001) \\
\end{array}$ & $\begin{array}{c}0.293 \\
(0.001) \\
\end{array}$ & $\begin{array}{c}0.251 \\
(0.001) \\
\end{array}$ & $\begin{array}{c}0.285 \\
(0.001) \\
\end{array}$ & $\begin{array}{c}0.243 \\
(0.001) \\
\end{array}$ & $\begin{array}{r}0.293 \\
(0.001) \\
\end{array}$ & $\begin{array}{r}0.259 \\
(0.001) \\
\end{array}$ \\
\hline CapEx(0)/FA & $\begin{array}{c}0.089 \\
(0.001) \\
\end{array}$ & $\begin{array}{c}0.015 \\
(0.167) \\
\end{array}$ & $\begin{array}{c}0.087 \\
(0.001) \\
\end{array}$ & $\begin{array}{c}0.013 \\
(0.239) \\
\end{array}$ & $\begin{array}{c}0.088 \\
(0.001) \\
\end{array}$ & $\begin{array}{c}0.014 \\
(0.189) \\
\end{array}$ & $\begin{array}{r}0.088 \\
(0.001) \\
\end{array}$ & $\begin{array}{c}0.014 \\
(0.186) \\
\end{array}$ \\
\hline Sales growth & $\begin{array}{r}0.015 \\
(0.091) \\
\end{array}$ & $\begin{array}{r}0.030 \\
(0.004) \\
\end{array}$ & $\begin{array}{r}0.009 \\
(0.323) \\
\end{array}$ & $\begin{array}{r}0.027 \\
(0.011) \\
\end{array}$ & $\begin{array}{r}0.009 \\
(0.322) \\
\end{array}$ & $\begin{array}{r}0.029 \\
(0.006) \\
\end{array}$ & $\begin{array}{r}0.010 \\
(0.278) \\
\end{array}$ & $\begin{array}{r}0.026 \\
(0.013) \\
\end{array}$ \\
\hline Tobin's q & $\begin{array}{c}0.013 \\
(0.001) \\
\end{array}$ & $\begin{array}{c}0.015 \\
(0.001) \\
\end{array}$ & $\begin{array}{c}0.020 \\
(0.001) \\
\end{array}$ & $\begin{array}{c}0.019 \\
(0.001) \\
\end{array}$ & $\begin{array}{c}0.020 \\
(0.001) \\
\end{array}$ & $\begin{array}{c}0.020 \\
(0.001) \\
\end{array}$ & $\begin{array}{c}0.019 \\
(0.001) \\
\end{array}$ & $\begin{array}{r}0.020 \\
(0.001) \\
\end{array}$ \\
\hline R-sq & 0.087 & 0.030 & 0.078 & 0.028 & 0.077 & 0.026 & 0.080 & 0.026 \\
\hline
\end{tabular}




\section{Table 12}

\section{Alternative measures of growth opportunities}

The sample period is 1970-1989. Included firms have $\$ 1$ billion of sales in 1989 dollars for each year in which they appear in the sample. All data are obtained from Compustat. CapEx is capital expenditures. De stands for depreciation. $F A(0)$ is the book value of fixed assets at the end of the base year. Employee growth is the percentage increase in employees from the base year to year +1 . Book leverage is the ratio of total debt to the book value of total assets at the end of the based year (TA). The industry $q$ is median $q$ of the industry. Market /book is the ratio of debt plus the market value of equity and of the book value of assets. Sales growth is the one year sales growth. p-values are in parentheses.

\begin{tabular}{|c|c|c|c|c|c|c|}
\hline $\begin{array}{l}\text { Dependent } \\
\text { variable } \\
\text { \# of obs }\end{array}$ & $\begin{array}{l}\text { CapEx-de } \\
\text { /FA(0) } \\
6791 \\
\end{array}$ & $\begin{array}{l}\text { Employee } \\
\text { growth } \\
6777 \\
\end{array}$ & $\begin{array}{l}\text { CapEx-de } \\
\text { /FA(0) } \\
6872 \\
\end{array}$ & $\begin{array}{l}\text { Employee } \\
\text { growth } \\
6858 \\
\end{array}$ & $\begin{array}{l}\text { CapEx-de } \\
\text { /FA(0) } \\
6791 \\
\end{array}$ & $\begin{array}{l}\text { Employee } \\
\text { growth } \\
6777 \\
\end{array}$ \\
\hline Intercept & $\begin{array}{r}0.002 \\
(0.559) \\
\end{array}$ & $\begin{array}{c}0.003 \\
(0.581) \\
\end{array}$ & $\begin{array}{r}0.004 \\
(0.313) \\
\end{array}$ & $\begin{array}{r}0.005 \\
(0.299) \\
\end{array}$ & $\begin{array}{r}0.002 \\
(0.581) \\
\end{array}$ & $\begin{array}{r}0.003 \\
(0.611) \\
\end{array}$ \\
\hline $\begin{array}{l}\text { Book leverage } \\
\text { Industry } q<1\end{array}$ & $\begin{array}{l}-0.103 \\
(0.001) \\
\end{array}$ & $\begin{array}{l}-0.085 \\
(0.001) \\
\end{array}$ & & & & \\
\hline $\begin{array}{l}\text { Book leverage } \\
\text { Industry } q>1\end{array}$ & $\begin{array}{l}-0.044 \\
(0.210) \\
\end{array}$ & $\begin{array}{c}0.031 \\
(0.533) \\
\end{array}$ & & & & \\
\hline $\begin{array}{l}\text { Book leverage } \\
\text { market/book<1 }\end{array}$ & & & $\begin{array}{l}-0.146 \\
(0.001)\end{array}$ & $\begin{array}{l}-0.127 \\
(0.001) \\
\end{array}$ & & \\
\hline $\begin{array}{l}\text { Book leverage } \\
\text { market/book }>1\end{array}$ & & & $\begin{array}{l}-0.001 \\
(0.977) \\
\end{array}$ & $\begin{array}{r}0.005 \\
(0.897) \\
\end{array}$ & & \\
\hline $\begin{array}{l}\text { Book leverage, } \\
\text { sales growth<0.05 }\end{array}$ & & & & & $\begin{array}{l}-0.091 \\
(0.001)\end{array}$ & $\begin{array}{l}-0.081 \\
(0.002) \\
\end{array}$ \\
\hline $\begin{array}{l}\text { Book leverage } \\
\text { sales growth }>0.05\end{array}$ & & & & & $\begin{array}{l}-0.086 \\
(0.002)\end{array}$ & $\begin{array}{l}-0.024 \\
(0.504)\end{array}$ \\
\hline Cash flow/TA -1 & $\begin{array}{r}0.286 \\
(0.001) \\
\end{array}$ & $\begin{array}{r}0.253 \\
(0.001) \\
\end{array}$ & $\begin{array}{r}0.269 \\
(0.001) \\
\end{array}$ & $\begin{array}{c}0.249 \\
(0.001) \\
\end{array}$ & $\begin{array}{r}0.287 \\
(0.001) \\
\end{array}$ & $\begin{array}{r}0.256 \\
(0.001) \\
\end{array}$ \\
\hline CapEx(0)/FA & $\begin{array}{c}0.088 \\
(0.001) \\
\end{array}$ & $\begin{array}{c}0.015 \\
(0.166) \\
\end{array}$ & $\begin{array}{r}0.088 \\
(0.001) \\
\end{array}$ & $\begin{array}{r}0.016 \\
(0.131) \\
\end{array}$ & $\begin{array}{r}0.088 \\
(0.001) \\
\end{array}$ & $\begin{array}{c}0.014 \\
(0.189) \\
\end{array}$ \\
\hline Sales growth & $\begin{array}{c}0.011 \\
(0.225) \\
\end{array}$ & $\begin{array}{r}0.027 \\
(0.017) \\
\end{array}$ & $\begin{array}{c}0.016 \\
(0.065) \\
\end{array}$ & $\begin{array}{r}0.034 \\
(0.003) \\
\end{array}$ & $\begin{array}{r}0.012 \\
(0.192) \\
\end{array}$ & $\begin{array}{c}0.027 \\
(0.014)\end{array}$ \\
\hline Tobin's q & $\begin{array}{c}0.019 \\
(0.001) \\
\end{array}$ & $\begin{array}{r}0.020 \\
(0.001) \\
\end{array}$ & $\begin{array}{r}0.025 \\
(0.001) \\
\end{array}$ & $\begin{array}{c}0.018 \\
(0.001)\end{array}$ & $\begin{array}{c}0.018 \\
(0.001) \\
\end{array}$ & $\begin{array}{r}0.018 \\
(0.001) \\
\end{array}$ \\
\hline R-sq & 0.080 & 0.027 & 0.080 & 0.025 & 0.079 & 0.026 \\
\hline
\end{tabular}


investment opportunities. When we do that, we find that there is no relation between growth and leverage for firms in industries where $q$ is greater than one. Second, we use market-to-book. Again, we find no relation between growth and leverage for high market-to-book firms, but we find a significant negative relation for low market-to-book firms. Finally, we use sales growth. This measure is not forward looking. The result that the relation between growth and leverage depends on q does not hold when we use this measure.

In table 13, we investigate altemative samples. We first address the issue of whether our results are due to using distressed firms in the sample. We therefore investigate the relation between leverage and growth for the better-performing firms. We show estimates that include only firms with a retum on assets above the sample median. It is not the case that the relation between leverage and growth only holds for the worst performing low-q firms. Consequently, our results cannot be explained by firms in distress. Although we do not report the results here, we also divided the sample into firms that perform better and worse than their industry median. Again, our results hold up for these two subsamples. To determine whether our results holds for the recent past, we show results for a sample that includes only the 1980s. We find that it does. In the last two columns of the table, we abandon our base sample altogether. These columns provide estimates for firms too small to belong in the base sample. Since there are a lot of firms with sales of less than $\$ 1$ billion, we had to restrict the sample and did so as follows. We choose only industrial firms with sales between $\$ 20$ million and $\$ 1$ billion. Our sample has the same number of firms each year. We sample randomly each year. A firm that appears in the sample in a given year can reappear four years later if it still exists and still satisfies our size restrictions. Clearly, the regressions for small firms lead to results very similar to those obtained for the base sample.

In table 14, we estimate our regressions annually to further investigate the robustness of the results. This approach allows the relation between growth and leverage to differ across years. It should be clear from the results in table 14 that there is a stable negative relation between leverage 


\section{Table 13}

Alternative samples

The sample period is 1970-1989. The base sample includes firms that have $\$ 1$ billion of sales in 1989 dollars for each year in which they appear in the sample. All data are obtained from Compustat. CapEx is capital expenditures. De stands for depreciation. $F A(0)$ is the book value of fixed assets at the end of the base year. Employee growth is the percentage increase in employee from the base year to year +1 . Book leverage is the ratio of total debt to the book value of total assets at the end of the based year (TA). The industry $q$ is the median $q$ of the industry. Market /book is the ratio of debt plus the market value of equity and of the book value of assets. Sales growth is the one-year sales growth. ROA denotes return on assets; industry ROA is the industry median. The small-firm sample includes a random sample firms with more than $\$ 20$ million but less than $\$ 1$ billion of sales for the year in which they appear in the sample.

\begin{tabular}{|c|c|c|c|c|c|c|}
\hline \multirow[b]{3}{*}{$\begin{array}{l}\text { Dependent } \\
\text { variable } \\
\text { \# of obs }\end{array}$} & \multicolumn{4}{|c|}{ Base sample } & \multirow{2}{*}{\multicolumn{2}{|c|}{ Small firm sample }} \\
\hline & \multicolumn{2}{|c|}{ ROA $>0.1767$} & \multicolumn{2}{|c|}{ Decade $=1980 \mathrm{~s}$} & & \\
\hline & $\begin{array}{l}\text { CapEx-de } \\
\text { /FA(0) } \\
3387 \\
\end{array}$ & $\begin{array}{l}\text { Employee } \\
\text { growth } \\
3406 \\
\end{array}$ & $\begin{array}{l}\text { CapEx-de } \\
\text { /FA(0) } \\
3475 \\
\end{array}$ & $\begin{array}{l}\text { Employee } \\
\text { growth } \\
3478 \\
\end{array}$ & $\begin{array}{l}\text { CapEx-de } \\
\text { /FA(0) } \\
3387\end{array}$ & $\begin{array}{l}\text { Employee } \\
\text { growth } \\
3406 \\
\end{array}$ \\
\hline Intercept & $\begin{array}{r}0.006 \\
(0.281) \\
\end{array}$ & $\begin{array}{c}0.002 \\
(0.700) \\
\end{array}$ & $\begin{array}{c}0.007 \\
(0.315) \\
\end{array}$ & $\begin{array}{c}0.005 \\
(0.551) \\
\end{array}$ & $\begin{array}{r}0.007 \\
(0.794) \\
\end{array}$ & $\begin{array}{r}0.002 \\
(0.916) \\
\end{array}$ \\
\hline Book leverage $q<1$ & $\begin{array}{l}-0.116 \\
(0.001) \\
\end{array}$ & $\begin{array}{l}-0.091 \\
(0.005) \\
\end{array}$ & $\begin{array}{l}-0.117 \\
(0.001) \\
\end{array}$ & $\begin{array}{l}-0.112 \\
(0.001) \\
\end{array}$ & $\begin{array}{r}-0.134 \\
(0.001) \\
\end{array}$ & $\begin{array}{r}-0.139 \\
(0.001) \\
\end{array}$ \\
\hline Book leverage $q>1$ & $\begin{array}{c}0.000 \\
(0.997) \\
\end{array}$ & $\begin{array}{c}0.118 \\
(0.271) \\
\end{array}$ & $\begin{array}{c}0.015 \\
(0.779) \\
\end{array}$ & $\begin{array}{c}0.073 \\
(0.285) \\
\end{array}$ & $\begin{array}{r}0.059 \\
(0.109) \\
\end{array}$ & $\begin{array}{r}-0.019 \\
(0.416) \\
\end{array}$ \\
\hline Cash flow $/ \mathrm{TA}$ & $\begin{array}{c}0.157 \\
(0.021) \\
\end{array}$ & $\begin{array}{c}0.124 \\
(0.032) \\
\end{array}$ & $\begin{array}{c}0.202 \\
(0.008) \\
\end{array}$ & $\begin{array}{c}0.192 \\
(0.002) \\
\end{array}$ & $\begin{array}{r}0.472 \\
(0.001) \\
\end{array}$ & $\begin{array}{r}0.346 \\
(0.001) \\
\end{array}$ \\
\hline CapEx(0)/FA & $\begin{array}{c}0.124 \\
(0.002) \\
\end{array}$ & $\begin{array}{c}-0.003 \\
(0.850) \\
\end{array}$ & $\begin{array}{c}0.084 \\
(0.001) \\
\end{array}$ & $\begin{array}{c}0.021 \\
(0.075) \\
\end{array}$ & $\begin{array}{r}0.004 \\
(0.028) \\
\end{array}$ & $\begin{array}{r}0.001 \\
(0.672) \\
\end{array}$ \\
\hline Sales growth & $\begin{array}{c}0.010 \\
(0.326) \\
\end{array}$ & $\begin{array}{c}0.012 \\
(0.302) \\
\end{array}$ & $\begin{array}{c}0.002 \\
(0.854) \\
\end{array}$ & $\begin{array}{c}0.013 \\
(0.200) \\
\end{array}$ & $\begin{array}{r}0.003 \\
(0.363) \\
\end{array}$ & $\begin{array}{r}0.002 \\
(0.295) \\
\end{array}$ \\
\hline Tobin's q & $\begin{array}{c}0.035 \\
(0.001) \\
\end{array}$ & $\begin{array}{c}0.037 \\
(0.001) \\
\end{array}$ & $\begin{array}{c}0.041 \\
(0.001) \\
\end{array}$ & $\begin{array}{c}0.040 \\
(0.001) \\
\end{array}$ & $\begin{array}{r}0.035 \\
(0.001) \\
\end{array}$ & $\begin{array}{r}0.020 \\
(0.001) \\
\end{array}$ \\
\hline R-sq & 0.053 & 0.012 & 0.091 & 0.0353 & 0.065 & 0.084 \\
\hline
\end{tabular}


Table 14

Summary results for yearly regressions

The regressions of table 6 are estimated for each year separately. The mean and median coefficients for the leverage variables are reported with the cross-sectional p-values reported in parentheses. The sample period is $1970-1989$. Included firms have $\$ 1$ billion of sales in 1989 dollars for each year in which they appear in the sample. All data are obtained from Compustat. CapEx is capital expenditures. De stands for depreciation. FA(0) is the book value of fixed assets at the end of the base year. Growth 1 (3) denotes growth measured over one (three) year(s), adjusted for inflation. Book leverage $B L$ is the ratio of total debt to the book value of total assets. $q$ is the ratio of the market value of equity plus the book value of debt to the replacement cost of the assets. BLLQ (BLHQ) is book leverage times an indicator variables that takes value one for firms with q smaller (greater) than one.

\begin{tabular}{|c|c|c|c|c|c|}
\hline $\begin{array}{l}\text { Dependent } \\
\text { variables } \\
\text { (\# regres- } \\
\text { sions) } \\
\end{array}$ & $\begin{array}{c}\text { CapEx-de/ } \\
\text { FA(0) } \\
(20)\end{array}$ & $\begin{array}{l}\text { Employee } \\
\text { growth } 1 \\
(20)\end{array}$ & $\begin{array}{l}\text { Employee } \\
\text { growth } 3 \\
\text { (17) }\end{array}$ & $\begin{array}{l}\text { CapEx } \\
\text { growth } 1 \\
(20)\end{array}$ & $\begin{array}{c}\text { CapEx } \\
\text { growth } 3 \\
(17)\end{array}$ \\
\hline $\begin{array}{l}\text { Mean BLLQ } \\
\text { coefficient } \\
\text { (p-value) }\end{array}$ & $\begin{array}{l}-0.119 \\
(0.001)\end{array}$ & $\begin{array}{l}-0.089 \\
(0.001)\end{array}$ & $\begin{array}{l}-0.223 \\
(0.001)\end{array}$ & $\begin{array}{l}-0.584 \\
(0.001) \\
\end{array}$ & $\begin{array}{l}-0.636 \\
(0.001) \\
\end{array}$ \\
\hline $\begin{array}{l}\text { Med. BLLQ } \\
\text { (p-value) } \\
\text { (\% positive) }\end{array}$ & $\begin{array}{l}-0.113 \\
(0.001) \\
5 \% \\
\end{array}$ & $\begin{array}{l}-0.110 \\
(0.003) \\
15 \% \\
\end{array}$ & $\begin{array}{l}-0.184 \\
(0.001) \\
12 \%\end{array}$ & $\begin{array}{l}-0.543 \\
(0.001) \\
0 \% \\
\end{array}$ & $\begin{array}{l}-0.680 \\
(0.001) \\
6 \% \\
\end{array}$ \\
\hline $\begin{array}{l}\text { Mean BLHQ } \\
\text { coefficient } \\
\text { (p-value) }\end{array}$ & $\begin{array}{l}-0.011 \\
(0.790)\end{array}$ & $\begin{array}{r}0.042 \\
(0.230)\end{array}$ & $\begin{array}{r}0.136 \\
(0.011) \\
\end{array}$ & $\begin{array}{l}-0.243 \\
(0.048) \\
\end{array}$ & $\begin{array}{r}0.071 \\
(0.660) \\
\end{array}$ \\
\hline $\begin{array}{l}\text { Med. BLHQ } \\
\text { (p-value) } \\
\% \text { positive }\end{array}$ & $\begin{array}{c}-0.013 \\
(0.668) \\
45 \%\end{array}$ & $\begin{array}{c}0.008 \\
(0.323) \\
55 \%\end{array}$ & $\begin{array}{c}0.122 \\
(0.005) \\
94 \%\end{array}$ & $\begin{array}{l}-0.223 \\
(0.058) \\
30 \%\end{array}$ & $\begin{array}{c}-0.130 \\
(0.530) \\
35 \%\end{array}$ \\
\hline
\end{tabular}


and growth for low-q firms and no such relation for high-q firms. Finally, we estimated the regressions using a fixed sample throughout the 20-year period. To save space, we do not reproduce these estimates. However, they support our results.

\section{Conclusion}

In this paper, we show that there is a negative relation between leverage and growth. Documenting such a relation is important, since many capital structure theories suggest that such a relation should exist because firms with high leverage might not be able to take advantage of growth opportunities, and because firms with poor growth opportunities should be prevented from dissipating cash flow on poor projects. Since managers choose leverage using their private information about the firm's growth opportunities, it could be that leverage proxies for growth opportunities. We addressed this issue by showing that the negative relation between growth and leverage holds for non-core segments of diversified firms also, even though one would expect the growth opportunities of non-core segments to have little impact on a firm's capital structure.

We then showed that the negative relation between growth and leverage exists only for low$q$ firms. This result holds:

1. Within and across industries

2. For different measures of leverage based on book values

3. For different measures of investment opportunities

4. For different estimation methods

5. For subsamples of better performing firms

6. For subperiods

7. For small firms

A number of authors have investigated the relation between liquidity and growth, proxying liquidity mostly by cash flow or liquid assets on hand. With few exceptions, these authors have paid 
little attention to leverage, even though the theoretical arguments used to motivate their research seem to apply more strongly to leverage than to operating cash flow. This is because increased leverage decreases both current funds available for investment and the firm's ability to raise additional funds to invest. We show that it is indeed the case that leverage matters more than operating cash flow.

In the literature on the relation between liquidity and growth, it has been difficult to determine the extent to which this relation is due to liquidity being a proxy for future growth. For instance, firms with low cash flow could have low investment simply because they have few worthwhile investment opportunities. This difficulty led authors to focus their investigation on subsamples where this spurious causation is unlikely to be important. We pursue the same approach in this paper when we focus on the capital expenditures of non-core segments of diversified firms. For these segments, leverage should matter little if its success at the firm-level regressions is due to its role as a proxy for future growth. In contrast, we find that leverage is as important for non-core segments as it is at the firm level.

Finding that leverage is negatively associated with growth only for low-q firms suggests that the negative effect of leverage on growth affects only those firms with good investment opportunities that the market does not recognize and those firms that do not have good investment opportunities, but might want to grow anyway. If the sample of low-q firms is mostly composed of firms that have marginal growth opportunities and poor performance, the fact that leverage acts like a brake on their growth might be beneficial for their shareholders. It might also provide support for capital structure theories, such as Jensen (1986) and Stulz (1990), which emphasize the disciplinary role of debt. 


\section{References}

Bernanke, B., M. Gertler, and S. Gilchrist, 1993, The financial accelerator and the flight to quality, Unpublished working paper (Princeton University, Princeton, NJ).

Bradley, M., G. Jarrell and E.H. Kim, 1984, On the existence of an optimal capital structure: Theory and evidence, Journal of Finance 39, 857-878.

Cantor, R., 1990, Effects of leverage on corporate investment and hiring decisions, Federal Reserve Bank of New York Quarterly Review (Summer), 31-41.

Fazzani, S., R. Glenn Hubbard and B. Petersen, 1988, Finance constraints and corporate investment, Brookings Papers on Economic Activity 1, 141-195.

Harris, M. and A. Raviv, 1991, The theory of capital structure, The Journal of Finance 46, 297 355.

Hoshi, T., A. Kashyap and D. Scharfstein, 1991, Corporate structure, liquidity, and investment: Evidence from Japanese panel data, Quarterly Journal of Economics 106, 33-60.

Jensen, M.C., 1986, Agency costs of free cash flow, corporate finance and takeovers, American Economic Review 76, 323-329.

Jung, K. Y.-C. Kim, and R.M. Stulz, 1995, Timing, Investment opportunities, managerial discretion, and the security issue decision, Unpublished working paper (The Ohio State University, Columbus, $\mathrm{OH})$.

Kaplan, S.N., and L. Zingales, 1995, Do financing constraints explain why investment is correlated with cash flow?, Unpublished working paper (University of Chicago, Chicago, ILL).

Kopcke, R.W. and M.M. Howrey, 1994, A panel study of investment: Sales, cash flow, the cost of capital, and leverage, New England Economic Review (January-February), 9-30.

Lamont, O., 1993, Cash flow and investment: Evidence from internal capital markets, unpublished paper (Massachusetts Institute of Technology, Cambridge, MA).

Lang, L., R.M. Stulz and R. Walkling, 1989, Managerial performance, Tobin's $q$ and the gains 
from successful tender offers, Joumal of Financial Economics 24, 1370154.

Lindenberg, E.B. and S.A. Ross, 1981, Tobin's q ratio and industrial organization, Joumal of Business 54, 1-32.

Miller, M., 1991, Leverage, Journal of Finance 46, 479-488.

Myers, S., 1977, Determinants of corporate borrowing, Journal of Financial Economics 5, 147175.

Ofek, E., 1993, Capital structure and firm response to poor performance: An empirical analysis, Joumal of Financial Economics 34, 3-31.

Opler, T.C. and S. Titman, 1994, Financial distress and corporate performance, Journal of Finance 49, 1015-1040.

Sharpe, S.A., 1994, Financial market imperfections, firm leverage, and the cyclicality of employment, American Economic Review, 1060-1074.

Smith, C.W. and R. Watts, 1992, The investment opportunity set and corporate financing, dividend and compensation policies, Joumal of Financial Economics 32, 263-292.

Stulz, R.M., 1990, Managerial discretion and optimal financing policies, Joumal of Financial Economics 26, 3-27.

Whited, T., 1992, Debt, liquidity constraints, and corporate investment: Evidence from panel data, Joumal of Finance 47, 1425-1461. 